\title{
Heterocyclic Antioxidants in Nature: Coumarins
}

\author{
Maria João Matos, ${ }^{a,{ }^{*}}$ Saleta Vazquez-Rodriguez, ${ }^{a}$ André Fonseca, ${ }^{a, b}$ Eugenio Uriarte, ${ }^{b}$ \\ Lourdes Santana ${ }^{\mathrm{b}}$ and Fernanda Borges ${ }^{\mathrm{a},{ }^{*}}$
}

a CIQUP/Departamento de Química e Bioquímica, Faculdade de Ciências, Universidade do Porto, Rua Campo Alegre 687, 4169-007 Porto, Portugal

${ }^{b}$ Departamento de Química Orgánica, Facultad de Farmacia, Universidad de Santiago de Compostela, Campus Vida s/n, 15782, Santiago de Compostela, España

* Corresponding author: Tel: +351 220402 653; E-mail: mariacmatos@gmail.com, mfernandamborges@gmail.com

Keywords: Natural products $\bullet$ Coumarin scaffold $\bullet$ Antioxidants $\bullet$ Radicals scavenging

Abstract: Coumarins represent an important family of naturally occurring and/or synthetic oxygen-containing heterocycles, bearing a characteristic benzopyrone framework. These compounds are widely distributed both in human diet and therapeutics. Among other characteristics, several coumarin derivatives proved to have an interesting antioxidant profile. In the present review, an overview of natural coumarins and their role as antioxidants is presented and discussed.

\section{Introduction:}

Coumarins (Figure 1) are an important class of phytochemicals. Coumarins are chemical entities that can be found in several species of the plant's kingdom [1]. Some of these compounds are responsible for the organoleptic properties of the matrix in which they are present. Therefore, coumarins (molecules bearing a benzopyrone framework) represent an important class of naturally occurring and/or synthetic oxygen-containing heterocycles [2]. 


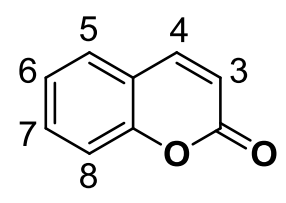

Figure 1 - Coumarin scaffold and numbering of the molecule.

Coumarins, a class of lactones bearing a $\pi-\pi$ conjugated electron-rich system composed by a benzene ring fused to $\alpha$-pyrone one, present specially good charge-transport properties [3]. The simplicity and chemical versatility of this scaffold are the key points for the wide range of applications $[4,5,6]$.

The coumarin name comes from the French term used to denominate the tonka bean coumarou- the natural source from which the coumarin was firstly isolated in 1820 [5]. This bean has a sweet odor, easy to be recognized as the scent of new-mown. Therefore, since 1882 coumarin has been used in perfumes. Plants produce it as a chemical defense to discourage predation [5].

In the last century, coumarins have been a topic of interest in areas as natural products, organic and medicinal chemistry. Therefore, the extraction, synthesis and biological study of coumarins have become an attractive rapidly developing research area [7]. Moreover, many coumarin and derivatives emerged as medicinal candidates or drugs presenting strong pharmacological activities. In most of the cases, these properties are accomplished of low toxic and low side effect, lower drug resistance, high bioavailability, wide spectrum of action, etc. [8,9]. Several efforts have been made centred in the development of coumarin-based anticoagulants, antioxidants, antimicrobials (anti-virals, antifungals and anti-parasitics), anticancer agents, anti-diabetics, analgesics, anti-neurodegenerative and anti-inflammatory agents, based on the properties of this naturally occurring family $[10,11,12,13]$.

Great efforts have been directed towards the extraction and purification of naturally occurring biologically active coumarins from a large variety of plants, animals and microorganisms. Similar efforts have been made towards the artificial synthesis of coumarin derivatives with novel structural features and biological properties $[14,15,16]$. These molecules have been increasingly attracting special interest as drugs due to their outstanding contributions in the prevention and treatment of several diseases. Over the years, coumarin-based research has become an extremely attractive area $[17,18,19]$. 
In this context, an overview of the role of natural coumarins as important antioxidants will be presented and discussed in the current review. During the research on the discovery of natural antioxidants from medicinal plants, some works reported the isolation of coumarin derivatives $[20,21,22,23]$. Epidemiological studies have correlated the ingestion of coumarinbased compounds in the diet with interesting benefits to health mainly due to their antioxidant activity [24]. The benefits of antioxidants to prevent chronic diseases were also already proven (Figure 2) [25].

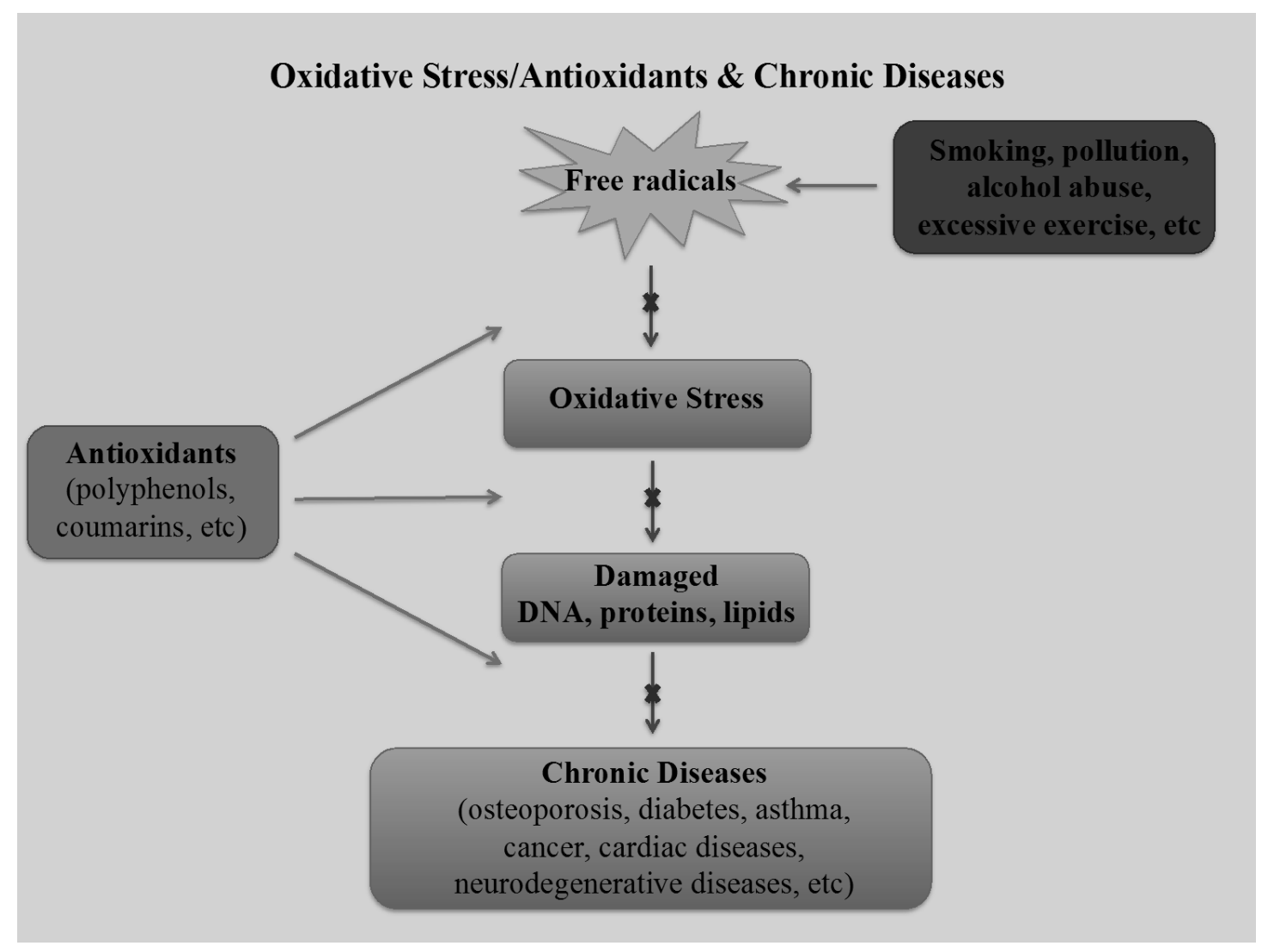

Figure 2 - Benefits of antioxidants in human health.

The most common assays performed to evaluate the antioxidant capacity described in this review are related to different reactive oxygen species (ROS) involved in the oxidative process: superoxide radical $\left(\mathrm{O}_{2}{ }^{--}\right)$, hydrogen peroxide $\left(\mathrm{H}_{2} \mathrm{O}_{2}\right)$, hypochlorous acid $(\mathrm{HOCl})$, nitric oxide $\left(\mathrm{NO}^{\circ}\right)$, peroxynitrite $\left(\mathrm{ONOO}^{-}\right)$, hydroxyl radical $\left(\mathrm{HO}^{\circ}\right)$, 2,2-diphenyl-1picrylhydrazyl radical ( $\mathrm{DPPH}^{\circ}$ ) and 2,2'-azino-bis(3-ethylbenzothiazoline)-6-sulphonic acid radical $\left(\mathrm{ABTS}^{\circ+}\right)$. 
Several reaction mechanisms were studied to investigate the antioxidant profile of coumarins. Among them, hydrogen atom transfer (HAT) and single electron transfer transfer (SET), were hightly cited.

The presence of hydroxyl groups in the coumarin scaffold contributes to prevent or minimize several types of oxidative processes [26]. It is recognized that the antioxidant effectiveness of coumarins, especially 4-hydroxycoumarins, is associated to the presence of those hydroxyl groups [27]. These substituents act as potent hydrogen donors contributing to the stability of the generated coumaric radical, due to electron delocalization across the molecule $[28,29]$. The potential of hydroxycoumarins as anti-inflammatory and antioxidant agents, along with the role of lipoic acid as endogenous thiol antioxidant, prompted the synthesis of hybrid derivatives that display higher $\mathrm{OH}$ scavenging activity than $\alpha$-lipoic acid itself [30].

\section{Simple coumarins as antioxidants:}

The coumarin itself, with no substitutions on it, was studied as an antioxidant agent [10]. Also, several naturally occurring simple coumarins were studied, presenting one or more hydroxyl groups on its structure. This is imperative for the presence of this activity. The most relevant examples, described in the last 30 years, are umbelliferone, scopoletin, umbelliferone 3-carboxylic acid, esculetin, 5,8-dihydroxycoumarin, daphnetin and fraxetin (Table 1). Since the experimental results were obtained in different sources, it is difficult to compare their real potential as antioxidants. However, some of the most relevant results are presented in this section.

Table 1 - Chemical structure of the simple coumarins described in this section.

\begin{tabular}{llllllll}
\hline Compounds & 3 & 4 & 5 & 6 & 7 & 8 \\
\hline Umbelliferone & $\mathrm{H}$ & $\mathrm{H}$ & $\mathrm{H}$ & $\mathrm{H}$ & $\mathrm{OH}$ & $\mathrm{H}$ \\
Scopoletin & $\mathrm{H}$ & $\mathrm{H}$ & $\mathrm{H}$ & $\mathrm{OCH}_{3}$ & $\mathrm{OH}$ & $\mathrm{H}$
\end{tabular}


Esculetin

5,8-

Dihydroxycoumarin

Daphnetin

Fraxetin

Scoparone

Crenulatin

Mansorin A

Mansorin B

Umbelliferone 3carboxylic acid

4,5-Dimethoxy-7methylcoumarin

4,7-Dimethoxy-5methylcoumarin

Isofraxidin

Fraxidin

(5,7-

Dimethoxycoumarin8-yl)acetaldehyde
$\mathrm{H}$

$\mathrm{H}$

$\mathrm{H}$

$\mathrm{H}$

$\mathrm{H}$

$\mathrm{H}$

$\mathrm{CH}_{3}$

$\mathrm{CH}_{3}$

$\mathrm{COOH}$

$\mathrm{H}$

$\mathrm{H}$

$\mathrm{H}$

$\mathrm{H}$

$\mathrm{H}$

H

$\mathrm{H}$

$\mathrm{H}$

$\mathrm{H}$

$\mathrm{OCH}_{3}$

$\mathrm{OH}$

H

H

$\mathrm{H}$

$\mathrm{H}$

$\mathrm{H}$

H

$\mathrm{H}$

$\mathrm{H}$

$\mathrm{H} \quad \mathrm{H}$

$\mathrm{OCH}_{3} \quad \mathrm{OCH}_{3}$

$\mathrm{OCH}_{3}$

$\mathrm{CH}_{3}$

$\mathrm{OH}$

$\mathrm{OH}$

$\mathrm{H}$

$\mathrm{H}$

$\mathrm{H}$

$\mathrm{OH}$

$\mathrm{H}$

$\mathrm{OH}$

$\mathrm{OH}$

$\mathrm{OCH}_{3}$

$\mathrm{OH}$

$\mathrm{OH}$

$\mathrm{OCH}_{3}$

$\mathrm{OCH}_{3}$

H

$\mathrm{CHO}$

$\mathrm{OCH}_{3}$

H

$\mathrm{CH}\left(\mathrm{CH}_{3}\right)_{2} \quad \mathrm{OCH}_{3}$

$\mathrm{H}$

$\mathrm{CH}_{3}$

$\mathrm{CH}\left(\mathrm{CH}_{3}\right)_{2} \quad \mathrm{OH}$

$\mathrm{H}$

$\mathrm{CH}_{3}$

$\mathrm{H}$

$\mathrm{OH}$

H

$\mathrm{H}$

$\mathrm{CH}_{3}$

$\mathrm{H}$

$\mathrm{H}$

$\mathrm{OCH}_{3}$

$\mathrm{H}$

$\mathrm{H} \quad \mathrm{OCH}$

$\mathrm{OH}$

$\mathrm{OCH}_{3}$

$\mathrm{OCH}_{3}$

$\mathrm{OCH}_{3}$

$\mathrm{OH}$

Umbelliferone and scopoletin were deeply studied and described as antioxidant [31]. Both compounds were presented in big amounts in ethyl acetate and methanol bark extracts of Melicope glabra [31,32]. These extracts were evaluated for their antioxidant capacities by DPPH scavenging activity and $\beta$-carotene bleaching/linoleic acid system. Both extracts exhibited strong inhibition against the DPPH $\left(\mathrm{IC}_{50}\right.$ values of 24.81 and $13.01 \mu \mathrm{g} / \mathrm{mL}$, respectively) and strong antioxidant activity in $\beta$-carotene bleaching assay. Both samples were found to have high phenolic content with values of 39 and $44 \mathrm{mg} \mathrm{GAE} / \mathrm{g}$ (gallic acid equivalents/gram) as indicated by Follin-Ciocalteau's reagent [32].

The antioxidant profile of the isolated umbelliferone was studied: Scavenging of $\mathrm{DPPH} \mathrm{IC}_{50}>$ 
$200 \mu \mathrm{M}$, scavenging of $\mathrm{OH} \mathrm{IC}_{50}>5000 \mu \mathrm{M}$, scavenging $\mathrm{O}_{2}{ }^{-{ }^{-}} \mathrm{IC}_{50}=26.7 \mu \mathrm{M}$, scavenging $\mathrm{HOClIC} C_{50}>2000 \mu \mathrm{M}$, scavenging $A B T S I C_{50}=0.53 \mu \mathrm{M}[24]$ and scavenging $\mathrm{ONOO}^{-} \mathrm{IC}_{50}=$ $36.28 \mu \mathrm{M}$ [33]. In the first report of the isolation and antioxidant potential of umbelliferone from Acacia nilotica, it was found that its antioxidant effect was dose-dependent up to 100 $\mu \mathrm{g} / \mathrm{mL}$ and then leveled off with no further increase in activity [34].

The profile of the isolated scopoletin was also evaluated: Scavenging of DPPH IC $50>200$ $\mu \mathrm{M}$, scavenging of $\mathrm{OH} \mathrm{IC}_{50}>5000 \mu \mathrm{M}$; scavenging $\mathrm{O}_{2}{ }^{--} \mathrm{IC}_{50}>200 \mu \mathrm{M}$, scavenging $\mathrm{HOCl}$ $\mathrm{IC}_{50}>2000 \mu \mathrm{M}$ and scavenging ABTS IC $\mathrm{C}_{50}=1.57 \mu \mathrm{M}[24]$.

Umbelliferone 3-carboxylic acid was extracted from Angelica decursiva, as umbelliferone, and was evaluated for its antioxidant profile: Scavenging of $\mathrm{DPPH} I \mathrm{IC}_{50}=681.86 \mu \mathrm{M}$; scavenging of $\mathrm{IC}_{50} \mathrm{ABTS}=11.20 \mu \mathrm{M}$; scavenging $\mathrm{NO} \mathrm{IC}_{50}>500 \mu \mathrm{M}$; scavenging $\mathrm{ONOO}^{-}$ $\mathrm{IC}_{50}=8.04 \mu \mathrm{M}$ [33].

Some dihydroxycoumarins have also been ascribed as antioxidant agents [35,36]. Esculetin (6,7-dihydroxycoumarin) isolated from Angelica decursiva, Angelica dahurica and Fraxinus chinensis $[24,37,38]$, was studied for its scavenging capacity against different radicals: Scavenging of DPPH IC $50=17.2 \mu \mathrm{M}$; scavenging of $\mathrm{OH}_{50} \mathrm{IC}_{50}=2783 \mu \mathrm{M}$; scavenging $\mathrm{O}_{2}{ }^{-}$ $\mathrm{IC}_{50}=2.3 \mu \mathrm{M}$; scavenging $\mathrm{HOCl} \mathrm{IC} \mathrm{I}_{50}>2000 \mu \mathrm{M}$; scavenging $A B T S \mathrm{IC}_{50}=2.45 \mu \mathrm{M}$ [24]. Esculetin showed one of the strongest antioxidant activities [39] of the tested compounds, showing in particular one of the strongest scavenging activities against DPPH [37].

5,8-Dihydroxycoumarin was isolated and studied from aerial parts of sweet grass (Hierochloë odorata L.). A clear linear dependency of radical scavenging capacity for this coumarin in DPPH and ABTS assays was determined. Although the basic principles of these reactions are similar, the ABTS scavenging assay is preferable for its ability to evaluate radical scavenging characteristics of both lipophilic and hydrophilic antioxidants, and the $\mathrm{IC}_{50}$ value of 5,8 -dihydroxycoumarin in DPPH assay was $0.0185 \%$, while in the ABTS reaction it was remarkably higher, $0.028 \%$ [40].

Daphnetin, the 7,8-dihydroxycoumarin, isolated from Gerbera piloselloides [41] showed antioxidant activity in the DPPH assay, as much of the other simple hydroxycoumarins, and fraxetin (extracted from Angelica dahurica) also showed antioxidant activity by inhibiting lipid peroxidation [42]: Daphnetin - scavenging of DPPH IC $50=20.6 \mu \mathrm{M}$, scavenging of $\mathrm{OH} I \mathrm{IC}_{50}=$ 
$3182 \mu \mathrm{M}$, scavenging $\mathrm{O}_{2}{ }^{-}{ }^{-} \mathrm{IC}_{50}=3.2 \mu \mathrm{M}$, scavenging $\mathrm{HOCl} \mathrm{IC}_{50}>2000 \mu \mathrm{M}$ and scavenging ABTS IC ${ }_{50}=2.15 \mu \mathrm{M}$ [24]; Fraxetin - scavenging of DPPH IC $50=44.1 \mu \mathrm{M}$, scavenging of $\mathrm{IC}_{50}$ ABTS $=37.4 \mu \mathrm{M}$ and scavenging of $\mathrm{H}_{2} \mathrm{O}_{2} \mathrm{IC}_{50}=40.5 \mu \mathrm{M}$ [39].

Scoparone and crenulatin were isolated from the crude acetone extract of the roots of Citrus hystrix in 2013 [43] and the potential of the plant extract as antioxidant was determined: $\mathrm{IC}_{50}$ values of 0.21 and $3.7 \mathrm{mg} / \mathrm{mL}$ in $\mathrm{DPPH}$ and $\mathrm{OH}$ assays, respectively [43].

New coumarins mansorin A and mansorin B were isolated from Mansonia gagei, but from the extract mansonone $\mathrm{N}$ (non coumarinic compound) was the only isolated product that showed radical scavenging properties [44].

Constituents of the root of Anemone tomentosa were isolated and evaluated as antioxidants [45]. 4,5-Dimethoxyl-7-methylcoumarin, 4,7-dimethoxy-5-methylcoumarin, isofraxidin and fraxidin [42] were tested for their capacity of scavenging the DPPH, presenting $\mathrm{IC}_{50}$ values of $75.16,78.28,51.25$ and $53.31 \mu \mathrm{M}$, respectively [45].

Isofraxidin was also isolated from Anneslea fragrans var. lanceolata, and its profile as antioxidant was also evaluated: Scavenging of DPPH IC $I_{50}=51.6 \mu \mathrm{M}$ and scavenging of $\mathrm{IC}_{50}$ ABTS $=1277.3 \mu \mathrm{M}[46]$.

Antioxidant potential and phenolic constituents of Salvia cedronella and Murraya alata were determined $[47,48]$ Some coumarins are presented in both extracts, but in the first case the antioxidant profile was only evaluated to different fractions of the extract. In the second one, the inhibitory profile of 2-(5,7-dimethoxycoumarin-8-yl)acetaldehyde on lipopolysaccharideactivated (LPS-activated) NO production in RAW 264.7 cells was evaluated: $I_{50}=13.8 \mu \mathrm{M}$ [48].

SAR studies on these particular compounds showed that the introduction of short-chain substituents provides more active compounds than the long-chain ones [49]. In general, esculetin showed the strongest quenching capacities against $\mathrm{DPPH}, \mathrm{OH}$ radicals, followed by daphnetin [24].

\section{Aliphatic, terpenoid and aromatic-containing coumarins as antioxidants:}


Coumarins bearing terpenoid-like, aromatic, or random aliphatic substituents were also found in different natural sources. Some of them have been isolated and fully characterized, and presented interesting antioxidant properties. The structures of these compounds are summarized in Table 2.

Table 2. Chemical structure of aliphatic, terpenoid and aromatic-containing coumarins described in this section.

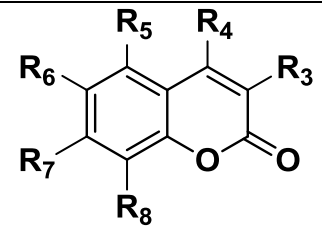

\begin{tabular}{|c|c|c|c|c|c|c|}
\hline Compounds & $\mathbf{R}_{3}$ & $\mathbf{R}_{4}$ & $\mathbf{R}_{5}$ & $\mathbf{R}_{6}$ & $\mathbf{R}_{7}$ & $\mathbf{R}_{8}$ \\
\hline Armenin & $\mathrm{H}$ & $\mathrm{H}$ & $\mathrm{H}$ & $\mathrm{H}$ & $\mathrm{OH}$ & \\
\hline Isoarmenin & $\mathrm{H}$ & $\mathrm{H}$ & $\mathrm{H}$ & $\mathrm{H}$ & & $\mathrm{OH}$ \\
\hline Lacarol & $\mathrm{H}$ & $\mathrm{H}$ & $\mathrm{OH}$ & $\mathrm{H}$ & $\mathrm{OCH}_{3}$ & \\
\hline Deoxylacarol & $\mathrm{H}$ & $\mathrm{H}$ & $\mathrm{H}$ & $\mathrm{H}$ & $\mathrm{OCH}_{3}$ & \\
\hline Peroxytamarin & $\mathrm{H}$ & $\mathrm{H}$ & $\mathrm{H}$ & & $\mathrm{OCH}_{3}$ & $\mathrm{H}$ \\
\hline $\begin{array}{l}\text { 6-(2,3-Dihydroxy-3- } \\
\text { methylbutyl)-7- } \\
\text { methoxycoumarin }\end{array}$ & $\mathrm{H}$ & $\mathrm{H}$ & $\mathrm{H}$ & & $\mathrm{OCH}_{3}$ & $\mathrm{H}$ \\
\hline Suberosin & $\mathrm{H}$ & $\mathrm{H}$ & $\mathrm{H}$ & & $\mathrm{OCH}_{3}$ & $\mathrm{H}$ \\
\hline Tamarin & $\mathrm{H}$ & $\mathrm{H}$ & $\mathrm{H}$ & & $\mathrm{OCH}_{3}$ & $\mathrm{H}$ \\
\hline $\begin{array}{l}\text { 7-Methoxy-8-(3-methyl-2,3- } \\
\text { epoxy-1 oxobutyl) } \\
\text { chromen-2-one }\end{array}$ & $\mathrm{H}$ & $\mathrm{H}$ & $\mathrm{H}$ & & $\mathrm{OCH}_{3}$ & $\mathrm{H}$ \\
\hline Osthenol & $\mathrm{H}$ & $\mathrm{H}$ & $\mathrm{H}$ & $\mathrm{H}$ & $\mathrm{OH}$ & \\
\hline Osthole & $\mathrm{H}$ & $\mathrm{H}$ & $\mathrm{H}$ & $\mathrm{H}$ & $\mathrm{OCH}_{3}$ & \\
\hline Yuehgesin B & $\mathrm{H}$ & $\mathrm{H}$ & $\mathrm{H}$ & $\mathrm{H}$ & $\mathrm{OCH}_{3}$ & \\
\hline Micromarin-F & $\mathrm{H}$ & $\mathrm{H}$ & $\mathrm{H}$ & $\mathrm{H}$ & $\mathrm{OCH}_{3}$ & \\
\hline Hassanon & $\mathrm{H}$ & $\mathrm{H}$ & $\mathrm{H}$ & $\mathrm{H}$ & $\mathrm{OCH}_{3}$ & \\
\hline Albiflorin-3 & $\mathrm{H}$ & $\mathrm{H}$ & $\mathrm{H}$ & $\mathrm{H}$ & $\mathrm{OCH}_{3}$ & \\
\hline 7-O-Methylphellodenol-B & $\mathrm{H}$ & $\mathrm{H}$ & $\mathrm{H}$ & $\mathrm{H}$ & $\mathrm{OCH}_{3}$ & \\
\hline $\begin{array}{c}\text { (Z)-5,7-Dimethoxy-8-(3- } \\
\text { methylbuta-1,3-dien-1- } \\
\text { yl)coumarin }\end{array}$ & $\mathrm{H}$ & $\mathrm{H}$ & $\mathrm{OCH}_{3}$ & $\mathrm{H}$ & $\mathrm{OCH}_{3}$ & \\
\hline Toddalenone & $\mathrm{H}$ & $\mathrm{H}$ & $\mathrm{OCH}_{3}$ & $\mathrm{H}$ & $\mathrm{OCH}_{3}$ & \\
\hline
\end{tabular}


<smiles>[R]c1c([R])c([R3])c2c([R3])c([R3])c(=O)oc2c1[R]</smiles>

\begin{tabular}{|c|c|c|c|c|c|c|}
\hline Compounds & $\mathbf{R}_{\mathbf{3}}$ & $\mathbf{R}_{\mathbf{4}}$ & $\mathbf{R}_{5}$ & $\mathbf{R}_{6}$ & $\mathbf{R}_{7}$ & $\mathbf{R}_{\mathbf{8}}$ \\
\hline Mammea B/BD & $\mathrm{H}$ & $\operatorname{Pr}$ & $\mathrm{OH}$ & & $\mathrm{OH}$ & \\
\hline Mammea B/BB & $\mathrm{H}$ & $\operatorname{Pr}$ & $\mathrm{OH}$ & & $\mathrm{OH}$ & \\
\hline $\begin{array}{c}\text { 6-Hydroxy-7-[(3,7- } \\
\text { dimethylocta-2(E),4(E),7- } \\
\text { trien-1-yl)oxy]coumarin }\end{array}$ & $\mathrm{H}$ & $\mathrm{H}$ & $\mathrm{H}$ & $\mathrm{OH}$ & & $\mathrm{H}$ \\
\hline Prenyletin & $\mathrm{H}$ & $\mathrm{H}$ & $\mathrm{H}$ & $\mathrm{OH}$ & & $\mathrm{H}$ \\
\hline Haplopinol & $\mathrm{H}$ & $\mathrm{H}$ & $\mathrm{H}$ & $\mathrm{OH}$ & & $\mathrm{H}$ \\
\hline $\begin{array}{l}\text { 6-Hydroxy-7-[(5-hydroxy- } \\
\text { 3,7-dimethylocta-2(E),6- } \\
\text { dien-1-yl)oxy]coumarin } \\
\text { 6-Hydroxy-7-[(7-hydroxy- }\end{array}$ & $\mathrm{H}$ & $\mathrm{H}$ & $\mathrm{H}$ & $\mathrm{OH}$ & & $\mathrm{H}$ \\
\hline $\begin{array}{l}\text { 3,7-dimethylocta-2(E),5(E)- } \\
\text { dien-1-yl)oxy]coumarin }\end{array}$ & $\mathrm{H}$ & $\mathrm{H}$ & $\mathrm{H}$ & $\mathrm{OH}$ & & $\mathrm{H}$ \\
\hline Auraptene & $\mathrm{H}$ & $\mathrm{H}$ & $\mathrm{H}$ & $\mathrm{H}$ & & $\mathrm{H}$ \\
\hline $\begin{array}{c}\text { 4-Hydroxy-7-methoxy-3- } \\
(3,7,11-\text { trimethyl-9- } \\
\text { oxododeca-3(E),7(Z)-dien-2- } \\
\text { yl)coumarin }\end{array}$ & & $\mathrm{OH}$ & $\mathrm{H}$ & $\mathrm{H}$ & $\mathrm{OCH}_{3}$ & $\mathrm{H}$ \\
\hline Fukanemarin $A$ & & $\mathrm{OH}$ & $\mathrm{H}$ & $\mathrm{H}$ & $\mathrm{OH}$ & $\mathrm{H}$ \\
\hline Fukanemarin B & & $\mathrm{OH}$ & $\mathrm{H}$ & $\mathrm{H}$ & $\mathrm{OCH}_{3}$ & $\mathrm{H}$ \\
\hline Glycyrin & & $\mathrm{H}$ & $\mathrm{OCH}_{3}$ & & $\mathrm{OCH}_{3}$ & $\mathrm{H}$ \\
\hline Glycycoumarin & & $\mathrm{H}$ & $\mathrm{OCH}_{3}$ & & $\mathrm{OH}$ & $\mathrm{H}$ \\
\hline $\begin{array}{l}\text { 3-(2,4-Dihydroxyphenyl)-5- } \\
\text { hydroxy-7-methoxy-8-(2- } \\
\text { methylbut-3-en-2- } \\
\text { yl)coumarin }\end{array}$ & & $\mathrm{H}$ & $\mathrm{OH}$ & $\mathrm{H}$ & $\mathrm{OCH}_{3}$ & \\
\hline $\begin{array}{l}\text { 3-(2,4-Dihydroxy-3-(3- } \\
\text { methylbut-2-en-1-yl)phenyl)- } \\
\text { 7-hydroxycoumarin }\end{array}$ & & $\mathrm{H}$ & $\mathrm{H}$ & $\mathrm{H}$ & $\mathrm{OH}$ & $\mathrm{H}$ \\
\hline Subcoriacin & & $\mathrm{H}$ & $\mathrm{H}$ & & $\mathrm{OH}$ & H \\
\hline 3'-Hydroxymelanettin & $\mathrm{H}$ & & $\mathrm{H}$ & $\mathrm{OH}$ & $\mathrm{OCH}_{3}$ & $\mathrm{H}$ \\
\hline Melanettin & $\mathrm{H}$ & & $\mathrm{H}$ & $\mathrm{OH}$ & $\mathrm{OCH}_{3}$ & $\mathrm{H}$ \\
\hline Fraxin & $\mathrm{H}$ & $\mathrm{H}$ & $\mathrm{H}$ & $\mathrm{OCH}_{3}$ & $\mathrm{OH}$ & \\
\hline
\end{tabular}




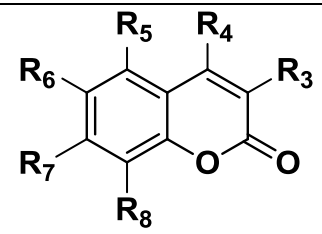

\begin{tabular}{|c|c|c|c|c|c|c|}
\hline Compounds & $\mathbf{R}_{\mathbf{3}}$ & $\mathbf{R}_{4}$ & $\mathbf{R}_{\mathbf{5}}$ & $\mathbf{R}_{6}$ & $\mathbf{R}_{7}$ & $\mathbf{R}_{8}$ \\
\hline Esculin & $\mathrm{H}$ & $\mathrm{H}$ & $\mathrm{H}$ & & $\mathrm{OH}$ & $\mathrm{H}$ \\
\hline Ferulsinaic Acid & $\mathrm{H}$ & $\mathrm{H}$ & $\mathrm{H}$ & $\mathrm{H}$ & & $\mathrm{H}$ \\
\hline
\end{tabular}

Mojarrab et al. studied $\mathrm{MeOH}$ extracts of the aerial parts of Artemisia armeniaca, and being able to isolate four coumarins (armenin, isoarmenin, lacarol and deoxylacarol). Their structures were determined by spectroscopic means, including UV, MS, 1D- and 2D-NMR. The in vitro free-radical scavenging properties of the extracts and of the isolated compounds were evaluated by the DPPH assay. The free radical scavenging activity in the DPPH assay was calculated as the concentration that caused a 50\% reduction in DPPH absorbance at $517 \mathrm{~nm}\left(\mathrm{RC}_{50}\right.$ expressed in $\left.\mathrm{mg} / \mathrm{mL}\right)$. The $\mathrm{MeOH}$ extract presented a $\mathrm{RC}_{50}=0.0317 \mathrm{mg} / \mathrm{mL}$, whereas from the isolated coumarins, lacarol was found to be the most active $\left(\mathrm{RC}_{50}=\right.$ $0.0302 \mathrm{mg} / \mathrm{mL}$ ) [50].

Panthong et al. isolated several coumarins from the acetone crude extract of the roots of Citrus hystrix. Their structures were determined and confirmed by analysis of $1 \mathrm{D}$ and 2D NMR spectroscopic data. The antioxidant activity using $\mathrm{DPPH}, \mathrm{OH}$ and $\mathrm{O}_{2}{ }^{--}$assays was assessed, but these compounds did not present significant antioxidant activity [43].

Osthole is a coumarin derivative that has been isolated from plants such as Prangos tschimganica [51] and Ostericum koreanum Maximowicz [52]. Ethyl acetate extracts of $O$. koreanum strongly scavenged $\mathrm{O}_{2}{ }^{--}, \mathrm{H}_{2} \mathrm{O}_{2}, \mathrm{OH}$ and $\mathrm{NO}$ with the $\mathrm{IC}_{50}$ being 23.582, 66.310, 170.582 and $60.779 \mathrm{mg} / \mathrm{mL}$, respectively and therefore presenting an antioxidant activity comparable to that of ascorbic acid [52]. It has also been demonstrate that osthole protect neuronal damage induced by significant reduction in the infarct volume, cerebral edema and the neurological deficit scores of rat submitted to middle cerebral artery occlusion (MCAO) due to a possible mechanisms in which its anti-oxidative action and anti-inflammatory property is involved [53]. In addition, osthole markedly inhibited the increased NO levels 
induced by intestinal $\mathrm{I} / \mathrm{R}$ injury, suggesting that osthole exerts therapeutic effects against intestinal I/R injury by attenuating oxidative stress, reducing excessive neutrophil infiltration and modulating NO levels [54].

Some 8-alkylcoumarins from the fruits of Cnidium monnieri have been isolated. From the isolated compounds, 7-O-methylphellodenol-B and 7-methoxy-8-(3-methyl-2,3-epoxy1oxobutyl)chromen-2-one, prove to protect against $\mathrm{H}_{2} \mathrm{O}_{2}$ induced oxidative stress damage [55]. Some other coumarins isolated from the leaves of Murraya alata such as toddalenone showed inhibition of NO production in LPS-induced RAW 264.7 macrophages with $\mathrm{IC}_{50}$ values between 6.0 and $14.5 \mu \mathrm{M}[48]$.

From the stem bark extract of Mammea usambarensis, two compounds namely mammea $\mathrm{B} / \mathrm{BB}$ and mammea $\mathrm{B} / \mathrm{BD}$ were isolated. These compounds showed antioxidant activities in DPPH assay at 4,012 and 2,176 $\mu \mathrm{mol} \mathrm{TE} / \mathrm{g}$, respectively. The potential antioxidant activities of these compounds may have been attributed by the presence of hydroxyl groups, which acts as good hydrogen donors. The lower activities of the isolated compounds compared to the crude extracts may be attributed to the synergistic effect [56].

Torres et al. isolate 8 coumarins from the resinous exudate of Haplopappus multifolius. The radical scavenging activity displayed by the extract $\left(\mathrm{IC}_{50}=45.5 \mathrm{mg} / \mathrm{mL}\right)$ by the DPPH assay confirmed the protective role of the resin towards ROS present in the environment. From the isolated coumarins, only the phenolic coumarins 7-((2E,4E)-3,7-dimethylocta-2,4,7-trien-1yl)oxy)-6-hydroxycoumarin, prenyletin, haplopinol, (Z)-6-hydroxy-7-((5-hydroxy-3,7dimethylocta-2,6-dien-1-yl)oxy)coumarin and 6-hydroxy-7-(((2E,5E)-7-hydroxy-3,7dimethylocta-2,5-dien-1-yl)oxy)coumarin displayed a moderate anti-oxidant activity ( $\mathrm{IC}_{50}$ $247.9,109.3,125.9,250.1$ and $251.5 \mu \mathrm{M}$, respectively) [57]. Other terpene-like coumarins such as auraptene, are a natural monoterpene isolated from plants of the genus Citrus. Some studies demonstrate that auraptene increased NO production and iNOS phosphorylation in auraptene-treated cells [58]. A 3-terpenoidcoumarin, 4-hydroxy-7methoxy-3-((3E,7Z)-3,7,11-trimethyl-9-oxododeca-3,7-dien-2-yl)coumarin, isolated from Ferula pallida also presented antioxidant properties showing values of inhibition percentage of lipid peroxidation and absorbance change due to scavenging of DPPH of $16.4 \%$ and 0.158 , respectively [51].

Fukanemarin $A$ and fukanemarin $B$ are sesquiterpene coumarin derivatives isolated from an 
$80 \%$ aqueous methanol extract of the roots of Ferula fukanensis (FFE). The FFE and the isolated coumarins inhibited NO production and induced NO synthase (iNOS) gene expression by a murine macrophage-like cell line (RAW 264.7), which was activated by LPS and recombinant mouse interferon- $\gamma$ (IFN- $\gamma$ ). FFE caused concentration-dependent inhibition of $\mathrm{NO}$ production by macrophages during incubation $\left(\mathrm{IC}_{50}=21.9 \mu \mathrm{g} / \mathrm{mL}\right)$, whereas fukanemarin $A$ and fukanemarin $B$ presented an inhibitory effect with $\mathrm{IC}_{50}$ values of 19.5 and $30.2 \mu \mathrm{M}$, respectively. Therefore these compounds inhibited iNOS mRNA expression in a dose-dependent manner. Inhibition of iNOS by these sesquiterpene coumarin derivatives may be mediated through the expression of these transcription-activating factors, thereby inhibiting iNOS transcription $[59,60]$.

Some 3-arylcoumarins have been isolated from Licorice, the root of Glycyrrhiza glabra. Antioxidant studies on these compounds by the Racimat method showed that some of the isolated coumarins glycyrin, glycycoumarin, 3-(2,4-dihydroxyphenyl)-5-hydroxy-7-methoxy-8(2-methylbut-3-en-2-yl)coumarin and 3-(2,4-dihydroxy-3-(3-methylbut-2-en-1-yl)phenyl)-7hydroxycoumarin presented good oxidation stability, with induction periods of 4.6, 3.5, 4.0, 8.9 hours, respectively, and protection factor values of $0.9,0.3,0.6$ and 2.7, respectively [61]. Additional antioxidant studies have been performed on glycycoumarin, which showed $\mathrm{EC}_{50}$ values of ABTS scavenging and inhibitory activity on lipid peroxidation of 4.32 and $11.9 \mu \mathrm{M}$, respectively [62], and DPPH scavenging activity $\mathrm{SC}_{50}$ of $7.92 \mu \mathrm{g} / \mathrm{mL}$ [63].

Another 3-arysubstituted coumarin, subcoriacin, isolated from Eysenhardtia subcoriacea was demonstrated to improve the endogenous antioxidant system. A significant increase in the activities of the antioxidant enzymes glutathione peroxidase (GSHPx), superoxide dismutase (SOD) and catalase (CAT) was observed. The increase in the activities of the antioxidant enzymes together with a decrease in blood glucose levels in both treatments demonstrate and support the relationship between the hypoglycemic and antioxidant activities displayed by subcoriacin [64].

Two 4-arylcoumarins, 3'-hydroxymelanettin and melanettin, were isolated and characterized from the ethyl acetate-soluble fraction of the heartwood of Dalbergia odorifera and it was studied their potential to inhibit the LPS-induced NO production in RAW 264.7 cells. The IC 50 values for the inhibitory effects of 3 '-hydroxymelanettin and melanettin were 45.5 and 53.2 $\mu \mathrm{M}$, respectively, indicating that these compounds are potential structural prototypes to treat anti-inflammatory diseases associated with the excess production of NO [65]. 
Some sugar-containing coumarins such as fraxin or esculin have also been isolated from natural sources. Lee et al. studied some antioxidant properties of fraxin isolated from Stewartia koreana, and they found that this compound showed DPPH and $\mathrm{O}_{2}{ }^{-{ }^{-}}$scavenging activities with $\mathrm{IC}_{50}$ values of 40.5 and $48.7 \mu \mathrm{g} / \mathrm{ml}$, respectively [66]. Esculin, isolated from Fraxinus chinensis extract (FCE), also presented a modest antioxidant activity. Data of the $\mathrm{SC}_{50}$ values for the FCE and esculin via the DPPH method were 50.0 and $133.3 \mu \mathrm{g} / \mathrm{ml}$, respectively [37].

Ferulsinaic acid $(F A)$ is the first member of a new rearranged class of sesquiterpene coumarins from the genus constituted by about 170 species of flowering plants in the family Apiaceae. Patients with diabetic nephropathy (DN) have decreased antioxidant enzyme expression and therefore the imbalance between the production of ROS and antioxidant defense mechanisms is believed to be involved [67]. Treatment of diabetic rats with FA significantly decreased the concentrations of the malondialdehyde (MDA) and significantly increased SOD, CAT, GSHPx activities and GSH concentrations in a dose-dependent manner, indicating that $\mathrm{FA}$ ameliorates oxidative stress in the diabetic rats [68].

A series of coumarin-chalcone derivatives was study in order to investigate the role of adjacent hydroxyl groups on the antioxidant proprieties. Different antioxidant mechanisms have been investigated, including HAT and SET. Based on the obtained results, the HAT mechanism was proposed as the most important one for the antioxidant protection exerted by this class of compounds [69]. Recently, different reaction mechanisms were investigated for this class of compounds. It was found that the largest contributions to the overall peroxyl radical scavenging activity of the studied compounds are the hydrogen transfer in lipid media, and the sequential proton loss hydrogen atom transfer (SPLHAT) in aqueous solution [70].

\section{Ring-fused coumarins as antioxidants:}

In the last years, several ring-fused coumarins, in particular pyrano- and furocoumarins, were isolated from natural sources and their antioxidant capacity was studied [71]. Some benzocoumarins and 1,4-dioxanecoumarins were also described. The activities of these ring-fused derivatives are related to the structural diversity of the substituents.

Two new 8-methylbenzo[ $h$ ]coumarins (Figure 3 ), muralatins $A$ and $B$, were isolated from the leaves of Murraya alata. Their inhibitory effects of the isolates on LPS-activated NO 
production in RAW 264.7 cells was evaluated: $\mathrm{IC}_{50}$ muralatin $\mathrm{A}=12.4 \mu \mathrm{M}$ and $\mathrm{IC}_{50}$ muralatin $\mathrm{B}=9.1 \mu \mathrm{M}$ [48]. Djalonensone and alternariol, benzo[c]coumarins, were isolated from the solid culture of the endophytic fungus Botryosphaeria dothidea $\mathrm{KJ}-1$, collected from the stems of white cedar (Melia azedarach L.) [72]. These metabolites showed no activity in DPPH assays [72].<smiles>[R]c1ccc2c(c1)cc(OC)c1ccc(=O)oc12</smiles>

Muralatin A: $\mathrm{R}=\mathrm{CH}_{3}$ Muralatin B: $\mathrm{R}=\mathrm{CH}_{2} \mathrm{OCOCH} \mathrm{H}_{2} \mathrm{CH}\left(\mathrm{CH}_{3}\right)_{2}$<smiles>[R]c1cc(O)c2c(=O)oc3cc(O)cc(C)c3c2c1</smiles>

Djalonensone: $\mathrm{R}=\mathrm{OCH}_{3}$

Alternariol: $\mathrm{R}=\mathrm{OH}$

Figure 3 - Examples of natural benzocoumarins.

Different pyranocoumarins (Figure 4) were isolated from the crude acetone extract of the roots of Citrus hystrix for the first time in 2013 [43]. The antioxidant profile of hystrixarin, trans-decursidinol and khellactone were determined. These compounds showed weaker activity than the crude extract, possibly indicating a synergistic effect in the crude extract; the values were not presented in the original manuscript [43]. Khellactone was also isolated from Polygonum amplexicaule, displaying moderated activity in the DPPH assay [73]. Effects of nordentatin, isolated from Citrus medica var, on NO production and DPPH scavenging activity were evaluated $\left(\mathrm{IC}_{50}=10.2 \mu \mathrm{M}\right.$ and $53.6 \mu \mathrm{M}$, respectively) [74].

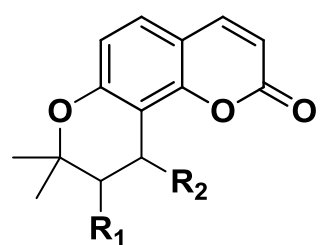

Hystrixarin: $\mathrm{R}_{1}=(R) \mathrm{OCOCH}_{2} \mathrm{CH}\left(\mathrm{CH}_{3}\right)_{2} ; \mathrm{R}_{2}=(R) \mathrm{OH}$ Khellactone: $\mathrm{R}_{1}=\mathrm{R}_{2}=\mathrm{OH}$<smiles>CC1(C)Oc2cc3oc(=O)ccc3cc2C(O)=C1O</smiles>

Decursidinol<smiles>C=CC(C)(C)c1c(O)c2c(c3ccc(=O)oc13)OC(C)(C)C=C2</smiles>

Nordentatin

Figure 4 - Examples of natural pyranocoumarins.

Some 1,4-dioxanecoumarins (Figure 5) were isolated from Acer saccharum [ 75 ]. Cleomiscosin $\mathrm{C}$ and one derivative were isolated from Hibiscus syriacus and proved to inhibited lipid peroxidation with $\mathrm{IC}_{50}$ values of 0.7 and $1.4 \mu \mathrm{g} / \mathrm{mL}$, respectively. 


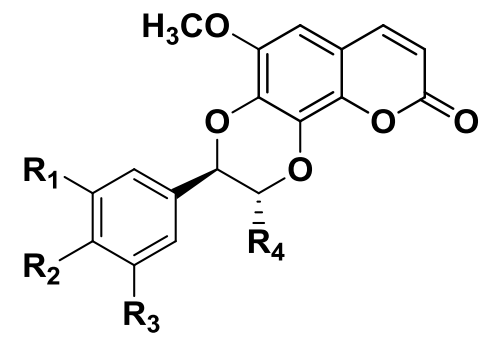

Cleomiscosin C: $\mathrm{R}_{1}=\mathrm{OCH}_{3} ; \mathrm{R}_{2}=\mathrm{OH} ; \mathrm{R}_{3}=\mathrm{OCH}_{3} ; \mathrm{R}_{4}=\mathrm{CH}_{2} \mathrm{OH}$

Cleomiscosin C derivative: $\mathrm{R}_{1}=\mathrm{OCH}_{3} ; \mathrm{R}_{2}=\mathrm{OH} ; \mathrm{R}_{3}=\mathrm{OCH}_{3} ; \mathrm{R}_{4}=\mathrm{CH}_{3}$

Figure 5 - Examples of 1,4-dioxanecoumarins.

Furocoumarins, based on the position of the furan-ring, are divided into the psoralen type (furan-ring at position 6,7 and also called linear-type) and the angelicin type (furan-ring at position 7,8 and also called angular-type). Structures of natural linear-furocoumarins and angular-furocoumarins with antioxidant activity are presented in tables 3 and 4 , respectively.

Table 3. Psoralens and dihydropsolarens.

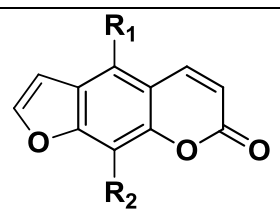

Psoralens

Psoralen

Bergapten

Xanthotoxol

Xanthotoxin

9-Hydroxy-4-methoxypsoralen

Isopimpinellin

Alloisoimperatorin

Imperatorin

Cnidilin
$\mathbf{R}_{1}$

$\mathrm{H}$

$\mathrm{OCH}_{3}$

$\mathrm{H}$

$\mathrm{H}$

$\mathrm{OCH}_{3}$

$\mathrm{OH}$

$\mathrm{OCH}_{3}$

$\mathrm{OCH}_{3}$

$\mathrm{OH}$

$\mathrm{CH}_{2} \mathrm{CH}=\mathrm{C}\left(\mathrm{CH}_{3}\right)_{2}$

$\mathrm{H}$

$\mathrm{OCH}_{3}$ 


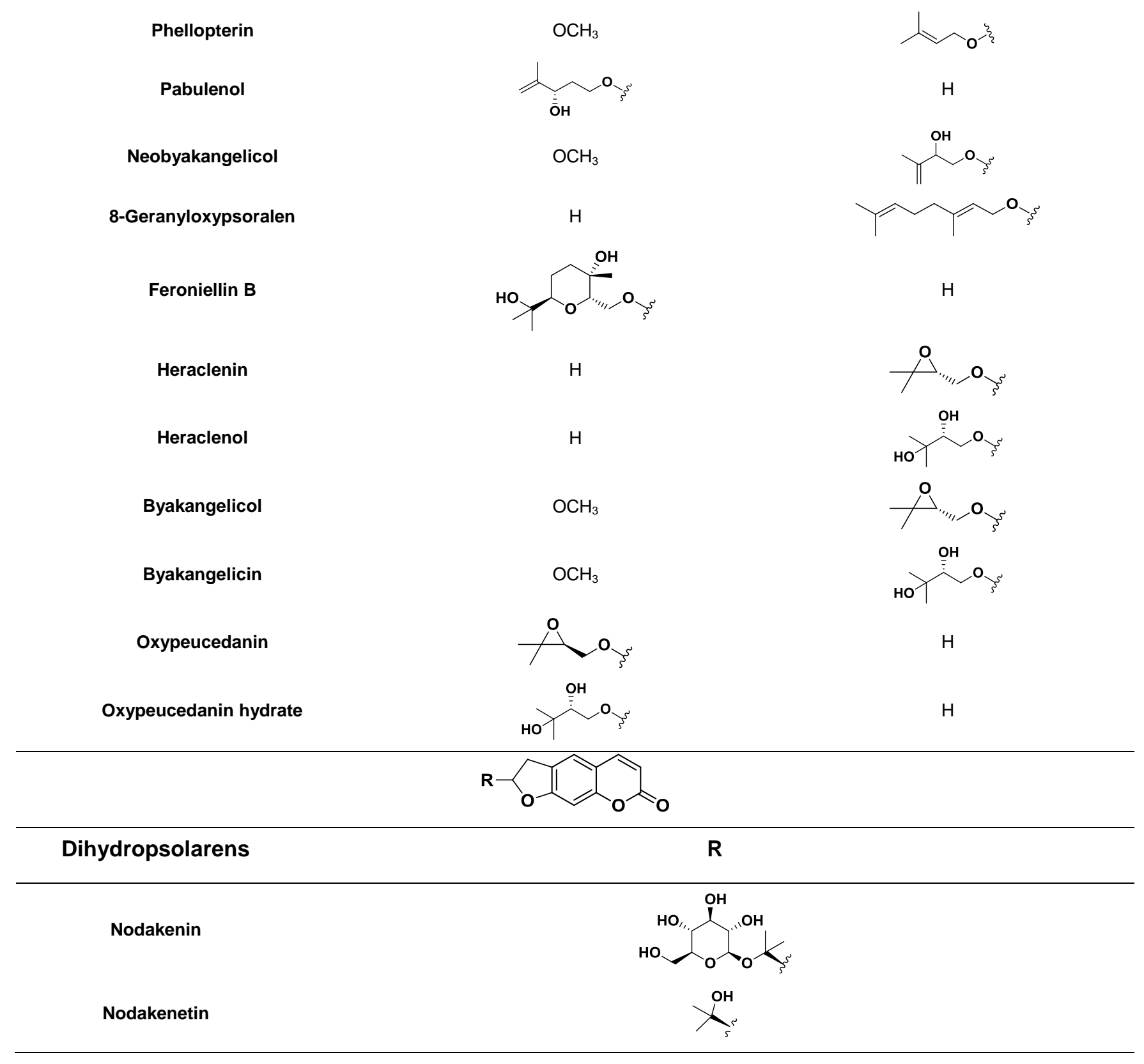

Table 4. Angelicins and dihydroangelicins.

\begin{tabular}{cccc}
\hline Angelicins & $\mathbf{R}_{1}$ & $\mathbf{R}_{\mathbf{2}}$ & $\mathrm{H}$ \\
\hline Angelicin & $\mathrm{H}$ & $\mathrm{H}$ & $\mathrm{H}$ \\
Isobergapten & $\mathrm{OCH}_{3}$ & $\mathrm{H}$ & $\mathrm{H}$ \\
\hline
\end{tabular}




\begin{tabular}{|c|c|c|c|}
\hline Pimpinellin & $\mathrm{OCH}_{3}$ & $\mathrm{OCH}_{3}$ & $\mathrm{H}$ \\
\hline Sphondin & $\mathrm{H}$ & $\mathrm{OCH}_{3}$ & $\mathrm{H}$ \\
\hline Oroselone & $\mathrm{H}$ & $\mathrm{H}$ & \\
\hline Dihydroangelicins & & $\mathbf{R}$ & \\
\hline Columbianetin & & & \\
\hline Columbianetin acetate & & & \\
\hline
\end{tabular}

Recently, it was reported the isolation of new furocoumarins from the aerial parts of Angelica urumiensis and Ammi majus used in traditional medicine [76,77]. The isolated furocoumarins showed to possess moderate antioxidant activity in DPPH scavenging assay.

Psoralen, isolated from P. tschimganic and Cachrys pungens Jan [78], exhibited $28.8 \%$ of inhibition of lipid peroxidation [51]. This compound has no capaciticy of DPPH scavenging [51].

Bergapten was isolated from Chinese herbs, and its effects on lipid peroxidation were determined: $22.15 \%$ in brain and $27.96 \%$ in kidney homogenates [79].

Xanthotoxol was isolated from $P$. tschimganica and its inhibition of lipid peroxidation in liposomes $\left(91.7 \%, \mathrm{IC}_{50}=50 \mu \mathrm{M}\right)$ and absorbance change due to scavenging of $\mathrm{DPPH}\left(\mathrm{IC}_{50}\right.$ $=0.331 \mu \mathrm{M})$, were calculated [51]. This compound was also isolated from Chinese herbs, and its effects on lipid peroxidation were determied: $71.31 \%$ in brain and $61.94 \%$ in kidney homogenates [79].

From the furocoumarin fraction from Angelica officinalis L. fruits they were isolated three major coumarins (imperatorin, xanthotoxin, and bergapten) that did not possess anti-radical activity against both DPPH and N,N-dimethyl-p-phenylendiamine (DMPD), while they exhibited a moderate level of ferric reduction activity potential (FRAP) and phosphomolybdenum-reducing antioxidant power (PRAP). In ferrous ion-chelation test, 
imperatorin had better activity than the other two tested coumarins [80]. Imperatorin was also extracted from genus Casimiroa (Rutaceae) seeds. To deeply study the activity of Casimiroa extracts and phyto-constituents it was determined their antioxidant capacity using the DPPH assay. Both Casimiroa edulis and Casimiroa pubescens elicited a concentration-dependent antioxidant activity, starting from $20 \mu \mathrm{g} / \mathrm{mL}$ and reaching an effect of $72.0 \%$ and $58.4 \%$ respectively, at the concentration of $600 \mu \mathrm{g} / \mathrm{mL}$. Among the isolated compounds imperatorin and 8-geranyloxypsoralen revealed higher antioxidant activity; unexpectedly, the latter exerts an evident activity reaching the $91.9 \%$ at $5.0 \mathrm{mM}$. Among the isolated compounds imperatorin revealed higher antioxidant activity; at the concentration of $5.0 \mathrm{mM}$, imperatorin showed an action of $73.8 \%$, with an $\mathrm{IC}_{50}$ of $2.25 \mathrm{mM}$ [81].

Xanthotoxin were then isolated from Cachrys pungens Jan from Italy, but it profile as antioxidant was not studied by this research group [78]. This compound was also isolated from Chinese herbs, and its effects on lipid peroxidation were determied: $8.36 \%$ in brain and $7.31 \%$ in kidney homogenates [79].

In vitro antioxidant capacity of roots of Ostericum koreanum maximowicz were studied. Oxypeucedanin hydrate was one of the most important constituents of the ethyl acetate extract of the roots. The ethyl acetate fraction of $O$. koreanum roots was subjected to in vitro antioxidant activity with different methods for free radical scavenging activities. Among all the tested methods, the ethyl acetate fraction was expressed very active, exhibiting a good Trolox equivalent values and $\mathrm{IC}_{50}$ comparable to that of the common antioxidants: Trolox and ascorbic acid [52].

Of all the compounds tested, isolated from Angelicae dahuricae, 9-hydroxy-4methoxypsoralen, and alloisoimperatorin showed the highest DPPH scavenging/reducing properties. Their $\mathrm{IC}_{50}$ were 6.1 and $9.4 \mu \mathrm{g} / \mathrm{mL}$, respectively, whereas for the other nine furocoumarins (namely oxypeucedanin hydrate, byakangelicin, pabulenol, neobyakangelicol, byakangelicol, oxypeucedanin and imperatorin, phellotorin) presented $I_{50}$ values were higher than $200 \mu \mathrm{g} / \mathrm{mL}$ [82].

Heraclenol was isolated from $P$. tschimganica and its inhibition of lipid peroxidation in liposomes $\left(87.2, I_{50}=75 \mu \mathrm{M}\right)$ and absorbance change due to scavenging of $\mathrm{DPPH}\left(\mathrm{IC}_{50}=\right.$ $0.019 \mu \mathrm{M})$, were calculated [51]. 
Effects of some furocoumarins isolated from Chinese Herbs on NO produced from RAW 264.7 cells (including byakangelicol, oxypeucedanin, oxypeucedanin hydrate, xanthotoxin and cnidilin) showed more than $50 \%$ inhibition of NO production at $20 \mathrm{mg} / \mathrm{mL}$. Also, some of these furocoumarins showed more inhibition effects of iNOS expression than both simple coumarins $[80,83]$.

Nodakenin and its aglycone nodakenetin, isolated from Angelica decursiva, were completely inactive at the concentrations tested in all the antioxidant assays used in this study: Scavenging of DPPH IC $\mathrm{I}_{50}>800 \mu \mathrm{M}$, scavenging ABTS IC ${ }_{50}>100 \mu \mathrm{M}$, scavenging of $\mathrm{NO}^{*}$ $\mathrm{IC}_{50}>500 \mu \mathrm{M}$ and scavenging $\mathrm{ONOO}^{-} \mathrm{IC}_{50}>50 \mu \mathrm{M}$. Nodakenetin exerted weak suppressive effects toward NO production with $20.72 \%$ inhibition at the concentration of 125 $\mu \mathrm{g} / \mathrm{mL}$ [33]. Nodakenin was also presented in the furocoumarin fraction from Angelica officinalis L. fruits [80].

Of the angelicin-type furocoumarins, angelicin (the simplest molecule of this series) showed a moderate inhibitory effect $(53.6 \%)$ on LPS-induced NO generation, in RAW 264.7 cells. Isobergapten, presenting a methoxy group at the position five, proved to display a considerably lower inhibitory activity $(8.8 \%)$. However, the similar compound sphondin (with methoxy group at position 6) showed a strong inhibitory effect. In addition, pimpinellin, presenting two methoxy groups both 5 and 6 positions, proved to be slightly active than angelicin. Therefore, the presence of a methoxy group at position 6 of the angular furocoumarin skeleton seems to be important to modulate the biological activity, and the addition of a methoxy group at position 5 proved to decrease the activity.

Regarding the psoralen-type furocoumarin series, psoralen (the simplest molecule of this series) proved to have significantly lower activity than angelicin. The activities of xanthotoxin and cnidilin, with a methoxy groups at position 8 , showed increased inhibitory effects (57.8 and $53.7 \%$, respectively). In addition, the presence of an additional dimethylallyoxy group at position 5 of the last one, seems to have no significant influence. This data was confirmed by comparing the chemical structure and biological activity of psoralen (27.1\%) and isoimperatorin (28.1\%). On the other hand, bergapten, presenting a methoxy group at position 5, proved to be inactive. Isopimpinellin (33.0\%), with two methoxy groups at positions 5 and 8, presented similar activity when compared to xanthotoxin (57.8\%). Oxypeucedanin $(53.7 \%)$ and oxypeucedanin hydrate $(83.2 \%)$ have on their structures oxidized prenyoxy groups at position 5. In these molecules the double bond of the 
dimethylallyoxy group is replaced by an epoxyl or two hydroxyl groups. This structural modification proved to be significantly important, increasing the actives comparing to the non-oxidative compound (isoimperatorin). However, analyzing the activities of byakangelicin, byakangelicol and phellopterin, only byakangelicol (presenting a dimethylallyoxy group saturated by an epoxyl at position 8 ) proved to display high activity. On the other hand, heraclenin, compared with byakangelicol, presenting the same moiety at position 8 but lacking a substitution at position 5 , proved to be inactive. Based on these results, functional substitutions on the benzene ring can selectively modulate NO production. The process is complex and cannot be simply explained based on hydrophilic or hydrophobic substitutions. In summary, the previous study clearly demonstrates that angelicins are more potent than psoralens. For the angelicins, the methoxy group at position 5 seems to be important for the activity. Regarding the psoralens, methoxy groups at position 8 or the double bond of the dimethylallyoxy group saturated by two hydroxyl groups at position 5 are responsible to the increasing of the activity. Comparing to the other furocoumarins tested, sphondin is the most potent inhibitor of NO production and iNOS expression in LPS-induced RAW 264.7 macrophages [83].

The main conclusion of this study was that sphondin can inhibit the induction of iNOS in LPS-activated murine macrophages. This conclusion was based on three main ideas: (1) The least nitrite accumulated in cell supernatants when sphondin was added simultaneously with LPS; a delayed addition resulted in a decreased effect; (2) Sphondin did not inhibit NO accumulation after LPS stimulation of RAW 264.7 cells, and did not show a direct effect on enzymatic activity of iNOS; (3) Western blot analyses demonstrated markedly reduced levels of iNOS protein in LPS-activated cells treated with sphondin as compared to untreated cells [83].

Angelicin was also isolated from Chinese herbs, and its effects on lipid peroxidation were determied: $16.32 \%$ in brain and $15.27 \%$ in kidney homogenates [79].

Feroniellin B was isolated from the extract of Feroniella lucida roots. The $\mathrm{IC}_{50}$ of the lipid peroxidation inhibition was $52 \mu \mathrm{M}$ [84].

Oroselone isolated from $P$. pabularia and Cachrys pungens Jan, exhibited $11.8 \%$ of inhibition of lipid peroxidation and 0.043 of capaciticy of DPPH scavenging [51]. Oroselone was also isolated from Chinese herbs, and its effects on lipid peroxidation were determied: 
$4.46 \%$ in brain and $-9.46 \%$ in kidney homogenates [79].

Columbianetin was isolated from Cachrys pungens Jan [78] and Chinese herbs, and its effects on lipid peroxidation were determied: $15.71 \%$ in brain and $6.67 \%$ in kidney homogenates [79]. Columbianetin acetate was also isolated from Chinese herbs, and its effects on lipid peroxidation were determied: $4.97 \%$ in brain and $4.73 \%$ in kidney homogenates [79].

Other angular dihydrofurocoumarins (dihydrofuro[3,2-c]coumarins) were isolated from natural sources and studied as antioxidant compounds (Table 5).

Table 5. Dihydrofuro[3,2-c]coumarins.<smiles>[R]c1ccc2c3c(c(=O)oc2c1)C([R3])C([R])O3</smiles>

$\begin{gathered}\text { Dihydrofuro[3,2- } \\ \text { C]coumarins }\end{gathered}$
Fukanefuromarin $\mathbf{A}$

2,3-Dihydro-7-hydroxy-2R,3R-dimethyl-2-[4,8-dimethyl-3(E),7-nonadien-6-onyl]furo[3,2c]coumarin $\left(\mathrm{IC}_{50}=24.6 \mu \mathrm{M}\right)$, fukanefuromarin $\mathrm{A}\left(\mathrm{IC}_{50}=13.0 \mu \mathrm{M}\right)$, fukanefuromarin $\mathrm{B}\left(\mathrm{IC}_{50}=\right.$ 
$16.2 \mu \mathrm{M})$, fukanefuromarin $\mathrm{C}\left(\mathrm{IC}_{50}=11.1 \mu \mathrm{M}\right)$ and fukanefuromarin $\mathrm{D}\left(\mathrm{IC}_{50}=8.9 \mu \mathrm{M}\right)$, were isolated from a $80 \%$ aqueous methanol extract of the roots of Ferula fukanensis and had stronger inhibition than quercetin on $\mathrm{NO}$ production $\left(\mathrm{IC}_{50}=31.2 \mu \mathrm{M}\right)$ [60]. The chloroform and water fractions showed $60 \%$ and $33.3 \%$ inhibition, respectively, at $30 \mu \mathrm{M}$.

Fukanefuromarin $\mathrm{E}$, fukanefuromarin $\mathrm{F}$ and fukanefuromarin $\mathrm{G}$ were isolated from aqueous methanol extract of the roots of Ferula fukanensis. The FFE and the isolated coumarins inhibited NO production and induced iNOS gene expression by a murine macrophage-like cell line (RAW 264.7), which was activated by LPS and recombinant mouse IFN- $\gamma$, as described before. FFE caused concentration-dependent inhibition of NO production by macrophages during incubation $\left(I_{50}=21.9 \mu \mathrm{g} / \mathrm{mL}\right)$, whereas fukanefuromarin $E$, fukanefuromarin $\mathrm{F}$ and fukanefuromarin $\mathrm{G}$ presented an inhibitory effect with $\mathrm{IC}_{50}$ values of $29.0 \mu \mathrm{M}, 30.7 \mu \mathrm{M}$ and $27.3 \mu \mathrm{M}$, respectively. Fukanefuromarin $\mathrm{E}$ proved to inhibit iNOS mRNA expression in a dose-dependent manner [59].

A series of polyhydroxycoumarins was studied, and in the experiments, a fundamental requirement for the expression of antioxidant activity appeared clearly to be, together with their redox properties, the ability to interact with biomembranes. Both HAT and SET mechanisms were described as possible for the antioxidant activity, but the electron delocalization stabilization as proposed in this study suggested the HAT mechanism to be a dominant factor for the AOA of coumarin derivatives. In conclusion, the antioxidant activity of coumarins appeared to be dictated not only by their structural features, but also by their location in the membrane [85].

\section{Ellagic acid derivatives as antioxidants:}

Ellagic acid (EA, Figure 6) and some of its derivatives natural phenolic antioxidants found in numerous fruits and vegetables such as Alpinia galangal, Alpinia calcarata [86], Psidium cattleianum [87], Polygonum runcinatum [88] or Oenothera paradoxa [89] among many others. Many studies demonstrate the ability of this compound, of the extracts containing this compound or their derivatives as potent antioxidants presenting scavenging activities for $\mathrm{O}_{2}{ }^{-2}$, $\mathrm{H}_{2} \mathrm{O}_{2}, \mathrm{HOCl}$, NO, ONOO${ }^{-}$and singlet oxygen $\left({ }^{1} \mathrm{O}_{2}\right)$ [87] and also good DPPH and ORAC IC $\mathrm{C}_{50}$ and FRAP EC ${ }_{1}[90]$. 
<smiles>O=c1oc2c(O)c(O)cc3c(=O)oc4c(O)c(O)cc1c4c23</smiles>

Figure 6. Chemical structure of ellagic acid.

\section{Acknowledgements}

This work was partially supported by Spanish researchers' personal funds, University of Santiago de Compostela, Foundation for Science and Technology (FCT) and QREN (FCUPCIQ-UP-NORTE-07-0124-FEDER-000065) projects. M.J.M. was supported by the postdoctoral fellowship from FCT, QREN and POPH (SFRH/BPD/95345/2013). S.V.R. was supported by the University of Porto postdoctoral fellowship (NORTE-07-0124-FEDER000065). A.F. was supported by the PhD scholarship from FCT, QREN and POPH (SFRH/BD/80831/2011).

[1] O'Kennedy, R. Coumarins. Biology, applications and mode of action. Wiley \& Sons: New York, 1997.

[2] Borges, F.; Roleira, F.; Milhazes, N.; Santana, L.; Uriarte, E. Simple coumarins and analogues in medicinal chemistry: Occurrence, synthesis and biological activity. Curr. Med. Chem. 2005, 12, 887-916.

[3] Borges, F Roleira, F.; Milhazes, N.; Uriarte, E.; Santana, L. Simple coumarins: Privileged scaffolds in medicinal chemistry. Front. Med. Chem. 2009, 4, 23-85.

[4] Murray, R.D.H. Naturally occurring plant coumarins. Prog. Chem. Org. Nat. Prod. 2002, 83, 1-673.

[5] Murray, R.D.H.; Mendez, J.; Brown, S.A. The natural coumarins occurrence, Wiley \& Sons: Chichester, UK, 1982.

[6] Qian, L.; Qian, L.-I.; Han, X.-e.; Han, H.; Chen, X.-z.; Yuan, H.-h. Research progress on coumarin and its derivatives. Guangzhou Huagong 2013, 41(1), 41-43.

[7] Wang, H.; Lu, X.; Yao, H.; Feng, J.; Liu, R. Research progress on application of coumarin and its derivatives. Chem. Ind. Times 2009, 23, 40-43.

[8] Zheng, L.; Zhao, T.; Sun, L. Research progress of the pharmacological action and pharmacokinetics of coumarins. Shizhen Guoyi Guoyao 2013, 24(3), 714-717.

[9] Lake, B.G. Coumarin metabolism, toxicity and carcinogenicity: relevance for human risk assessment. Food Chem. Toxicol. 1999, 37(4), 423-453. 
[10] Venugopala, K.N.; Rashmi, V.; Odhav, B. Review on natural coumarin lead compounds for their pharmacological activity. BioMed Res. Int. 2013, 963248, 14.

[11] Matos, M.J.; Viña, D.; Vazquez-Rodriguez, S.; Uriarte, E.; Santana, L. Focusing on new monoamine oxidase inhibitors: differently substituted coumarins as an interesting scaffold. Curr. Top. Med. Chem. 2012, 12(20), 2210-2239.

[12] Kostova, I. Synthetic and natural coumarins as cytotoxic agents. Curr. Med. Chem. 2005, 5, 29-46.

[13] Kostova, I. Coumarins as inhibitors of HIV reverse transcriptase. Curr. HIV Res. 2006, 4, 347-363.

[14] Sarker, D.S.; Nahar, L. An introduction to natural products isolation. Springer Science Business Media: LLC, 2012.

[15] Rodríguez, J.E.; López, O.D.; Gil, J.M. Método para la cuantificación de cumarina en extracto seco a partir de extractos de Justicia pectoralis Jacq. Rev. Cubana Plant. Med. 2008, 13(3), 1-7.

[16] Rodríguez, J.E.; Hernández, O.D.L.; Figueredo, Y.N.; Ferrada, C.R.; Mendoza, A.N. Obtención de extractos secos a partir de extractos acuosos de Justicia pectoralis (tilo). Rev. Cubana Plant. Med. 2013, 18(4), 543-554.

[17] Riveiro, M.E.; De Kimpe, N.; Moglioni, A.; Vázquez, R.; Monczor, F.; Shayo, C.; Davio, C. Coumarins: Old compounds with novel promising therapeutic perspectives. Curr. Med. Chem. 2010, 17, 1325-1338.

[18] Peng, X.M.; Damu, G.L.V.; Zhou, C.H. Current developments of coumarin compounds in medicinal chemistry. Curr. Pharm. Des. 2013, 19(21), 3884-3930.

[19] Kostova, I. Studying plant derived coumarins for their pharmacological and therapeutic properties as potential anticancer drugs. Expert Opin. Drug Discov. 2007, 2, 1605-1618.

[20] Min Kyun, N.; Phuong Thien, T.; Ki Hwan, B. Natural compounds with antioxidant activity: Recent findings from studies on medicinal plants. Nat. Prod. Sci. 2011, 17(2), 65-79.

[21] Grosso, C.; Valentão, P.; Ferreres, F.; Andrade, P.B. The use of flavonoids in central nervous system disorders. Curr. Med. Chem. 2013, 20(37), 4694-4719.

[22] Bubols, G.B.; Vianna, D.R.; Medina-Remon, A.; von Poser, G.; Lamuela-Raventos, R.M., Eifler-Lima, V.L.; Garcia, S.C. The antioxidant activity of coumarins and flavonoids. Mini Rev. Med. Chem. 2013, 13(3), 318-334.

[23] Aboul-Enein, H.Y.; Berczynsk, P.; Kruk, I. Phenolic compounds: The role of redox regulation in neurodegenerative disease and cancer. Mini Rev. Med. Chem. 2013, 13(3), 385-398.

[24] Thuong, P.T.; Hung, T.M.; Ngoc, T.M.; Ha do, T.; Min, B.S.; Kwack, S.J.; Kang, T.S.; Choi, J.S.; Bae, K. Antioxidant activities of coumarins from Korean medicinal plants and their structure-activity relationships. Phytother. Res. 2010, 24(1), 101-106.

[25] Willcox, J.K.; Ash, S.L.; Catignani, G.L. Antioxidants and prevention of chronic disease. Crit. Rev. Food Sci. Nutr. 2004, 44(4), 275-295.

[26] Fylaktakidou, K.C.; Hadjipavlou-Litina, D.J.; Litinas, K.E.; Nicolaides, D.N. Natural and synthetic coumarin derivatives with anti-inflammatory/antioxidant activities. Curr. Pharm. Des. 2004, 10(30), 3813-3833. 
[27] Keating, G.J.; O'Kennedy, R. The chemistry and occurrence of coumarins. Wiley \& Sons: West Sussex, England, 1997.

[28] Kostova, I. Synthetic and natural coumarins as antioxidants. Mini Rev. Med. Chem. 2006, 6(4), 365-374.

[29] Yordi, E.G.; Molina, E.; Matos, M.J.; Uriarte, E. Antioxidant and pro-oxidant effects of polyphenolic compounds and structure-activity relationship evidence. InTech: Croatia, 2012.

[ 30 ] Melagraki, G.; Afantitis, A.; Igglessi-Markopoulou, O.; Detsi, A.; Koufaki, M.; Kontogiorgis, C.; Hadjipavlou-Litina, D.J. Synthesis and evaluation of the antioxidant and anti-inflammatory activity of novel coumarin-3-aminoamides and their alpha-lipoic acid adducts. Eur. J. Med. Chem. 2009, 44(7), 3020-3026.

[31] Bansal, Y.; Sethi, P.; Bansal, G. Coumarin: a potential nucleus for anti-inflammatory molecules. Med. Chem. Res. 2013, 22(7), 3049-3060.

[32] Kassim, N.K.; Rahmani, M.; Ismail, A.; Sukari, M.A.; Ee, G.C.L.; Nasir, N.M.; Awang, K. Antioxidant activity-guided separation of coumarins and lignan from Melicope glabra (Rutaceae). Food Chem. 2013, 139, 87-92.

[33] Zhao, D.; Islam, Md.N.; Ahn, B.R.; Jung, H.A.; Kim, B.-W.; Choi, J.S. In vitro antioxidant and anti-inflammatory activities of Angelica decursiva. Arch. Pharm. Res. 2012, 35(1), 179192.

[34] Roma, G.C.; Furquim, K.C.; Bechara, G.H.; Camargo-Mathias, M.I. Permethrin-induced morphological changes in oocytes of Rhipicephalus sanguineus (Acari: Ixodidae) semiengorged females. Food Chem. 2010, 120(3), 825-830.

[35] Morabito, G.; Trombetta, D.; Singh Brajendra, K.; Prasad Ashok, K.; Parmar Virinder, S.; Naccari, C.; Mancari, F.; Saija, A.; Cristani, M.; Firuzi, O.; Saso, L. Antioxidant properties of 4-methylcoumarins in in vitro cell-free systems. Biochimie 2010, 92(9), 1101-1107.

[36] Gacche, R.N.; Jadhav, S.G. Antioxidant activities and cytotoxicity of selected coumarin derivatives: Preliminary results of a structure-activity relationship study using computational tools. J. Exp. Clin. Med. 2012, 4(3), 165-169.

[37] Lee, B.-C.; Lee, S.Y.; Lee, H.J.; Sim, G.-S.; Kim, J.-H.; Cho, Y.-H.; Lee, D.-H.; Pyo, H.B.; Choe, T.-B.; Moon, D.C.; Yun, Y.P.; Hong, J.T. Anti-oxidative and photo-protective effects of coumarins isolated from Fraxinus chinensis. Arch. Pharm. Res. 2007, 30(10), 1293-1301.

[38] Wang, C.; Pei, A.; Chen, J.; Yu, H.; Sun, M.-L.; Liu, C.-F.; Xu, X.J. A natural coumarin derivative esculetin offers neuroprotection on cerebral ischemia/reperfusion injury in mice. Neurochem. 2012, 121, 1007-1013.

[39] Wu, C.-R.; Huang, M.-Y.; Lin, Y.-T.; Ju, H.-Y.; Ching, H. Antioxidant properties of Cortex fraxini and its simple coumarins. Food Chem. 2007, 104(4), 1464-1471.

[ 40 ] Slapsyte, G.; Dedonyte, V.; Lazutka, J.R.; Mierauskiene, J.; Morkunas, V.; Kazernaviciute, R.; Pukalskas, A.; Venskutonis, P.R. Evaluation of the biological activity of naturally occurring 5,8-dihydroxycoumarin. Molecules 2013, 18, 4419-4436.

[41] Wang, J.; Petrova, V.; Wu, S.-B.; Zhu, M.; Kennelly, E.J.; Long, C. Total syntheses of racemic and natural glycinol. Nat. Prod. Res. 2014, 28(22), 2072-2075.

[42] Witaicenis, A.; Seito, L.N.; da Silveira Chagas, A.; de Almeida, L.D.; Luchini, A.C.; Rodrigues-Orsi, P.; Cestari, S.H.; Di Stasi, L.C. Antioxidant and intestinal anti-inflammatory effects of plant-derived coumarin derivatives. Phytomedicine 2014, 21(3), 240-246. 
[43] Panthong, K.; Srisud, Y.; Rukachaisirikul, V.; Hutadilok-Towatana, N.; Voravuthikunchai, S.P.; Tewtrakul, S. Benzene, coumarin and quinolinone derivatives from roots of Citrus hystrix. Phytochemistry 2013, 88, 79-84.

[44] Tiew, P.; loset, J.-R.; Kokpol, U.; Chavasiri, W.; Hostettmann, K. Antifungal, antioxidant and larvicidal activities of compounds isolated from the heartwood of Mansonia gagei. Phytother. Res. 2003, 17(2), 190-193.

[45] Hu, H.-B.; Zheng, X.-D.; Jian, Y.-F.; Liu, J.-X.; Zhu, J.-H. Constituents of the root of Anemone tomentosa. Arch. Pharm. Res. 2011, 34(7), 1097-1105.

[46] Huang, H.-Y.; Ko, H.-H.; Jin, Y.-J.; Yang, S.-Z.; Shih, Y.-A.; Chen, I.-S. Dihydrochalcone glucosides and antioxidant activity from the roots of Anneslea fragrans var. lanceolata. Phytochemistry 2012, 78, 120-125.

[47] Yesilyurt, V.; Halfon, B.; Ozturk, M.; Topcu, G. Antioxidant potential and phenolic constituents of Salvia cedronella. Food Chem. 2008, 108(1), 31-39.

[48] Lv, H.-N.; Wang, S.; Zeng, K.-W.; Li, J.; Guo, X.-Y.; Ferreira, D.; Zjawiony, J.K.; Tu, P.F.; Jiang, Y. Anti-inflammatory coumarin and benzocoumarin derivatives from Murraya alata. J. Nat. Prod. 2015, 78, 279-285.

[49] Lin, M.-H.; Chou, Y.-S.; Tsai, Y.-J.; Chou, D.-S. Antioxidant properties of 5,7dihydroxycoumarin derivatives in in vitro cell-free and cell-containing systems. J. Exp. Clin. Med. 2011, 3(3), 126-131.

[50] Mojarrab, M.; Delazar, A.; Moghadam, S.B.; Nazemiyeh, H.; Nahar, L.; Kumarasamy, Y.; Asnaashari, S.; Hadjiakhoondi, A.; Sarker, S.D. Armenin and isoarmenin - Two prenylated coumarins from the aerial parts of Artemisia armeniaca. Chem. Biodivers. 2011, 8, 20972103.

[51] Kogure, K.; Yamauchi, I.; Tokumura, A.; Kondou, K.; Tanaka, N.; Takaishi, Y.; Fukuzawa, K. Novel antioxidants isolated from plants of the genera Ferula, Inula, Prangos and Rheum collected in Uzbekistan. Phytomedicine. 2004, 11, 645-651.

[52] Mahesh, R.; Jung, H.W.; Park, J.H.; Park Y-K. In Vitro antioxidant capacity and neuronal cell toxicity of roots of Ostericum koreanum Maximowicz. E-Journal Chem. 2011, 8, 14511455.

[53] Chao, X.; Zhou, J.; Chen, T.; Liu, W.; Dong, W.; Qu, Y.; Jiang, X.; Ji, X.; Zhen, H.; Fei, Z. Neuroprotective effect of osthole against acute ischemic stroke on middle cerebral ischemia occlusion in rats. Brain Res. 2010, 1363, 206-211.

[54] Zhang, W. Protective effects of osthole, a natural derivative of coumarin, against intestinal ischemia-reperfusion injury in mice. Int. J. Mol. Med. 2013, 31, 1367-1374.

[55] Chang, C.I.; Hu, W.C.; Shen, C.P.; Hsu, B.D.; Lin, W.Y.; Sung, P.J.; Wang, W.H.; Wu, J.B.; Kuo, Y.H. 8-Alkylcoumarins from the fruits of Cnidium monnieri protect against hydrogen peroxide induced oxidative stress damage. Int. J. Mol. Sci. 2014, 15, 4608-4618.

[56] Magadula, J.J. Bioactive Mammea-type coumarins and benzophenones from two clusiaceae plants. J. Pharm. Sci. Innov. 2012, 1, 31-33.

[57] Torres R, Faini F, Modak B, Urbina, F.; Labbé, C.; Guerrero, J. Antioxidant activity of coumarins and flavonols from the resinous exudate of Haplopappus multifolius. Phytochemistry 2006, 67, 984-987. 
[58] Wang, S.; Yoon, Y.C.; Sung, M.J.; Hwang, J.T.; Hur, H.J.; Kim, H.J.; Yang, H.J.; Kim, M.S.; Kwon, D.Y.; Park, J.H. Citrus-derived auraptene stimulates angiogenesis by activating the Erk- and PI3K/Akt/eNOS-dependent signaling pathways in human umbilical vein endothelial cells. J. Funct. Foods. 2012, 4, 899-905.

[59] Motai, T.; Kitanaka, S. Sesquiterpene coumarins from Ferula fukanensis and production inhibitory effects. Chem. Pharm. Bull. 2004, 52, 1215-1218.

[60] Motai, T.; Daikona, A.; Kitanaka, S. Sesquiterpene chromones from Ferula fukanensis and their nitric oxide production inhibitory effects. J. Nat. Prod. 2004, 67, 432-436.

[61] Gordon, M.H.; An, J. Antioxidant activity of flavonoids isolated from Licorice. J. Agric. Food Chem. 1995, 43, 1784-1788.

[62] Fu, Y.; Chen, J.; Li, Y.J.; Zheng, Y.F.; Li, P. Antioxidant and anti-inflammatory activities of six flavonoids separated from Licorice. Food Chem. 2013, 141, 1063-1071.

[63] Li, Y.J.; Chen, J.; Li, Y.; Li, Q.; Zheng, Y.F.; Fu, Y.; Li, P. Screening and characterization of natural antioxidants in four Glycyrrhiza species by liquid chromatography coupled with electrospray ionization quadrupole time-of-flight tandem mass spectrometry. J. Chromatogr. A. 2011, 1218, 8181-8191.

[64] Narváez-Mastache, J.M.; Soto, C.; Delgado, G. Hypoglycemic and antioxidant effects of Rheum franzenbachii extract in streptozotocin-induced diabetic rats. J. Mex. Chem. Soc. 2010, 54, 240-244.

[65] Lee, C.; Lee, J.W.; Jin, Q.; Jang, D.S.; Lee, S.J.; Lee, D.; Hong, J.T.; Kim, Y.; Lee, M.K.; Hwang, B.Y. Inhibitory constituents of the heartwood of Dalbergia odorifera on nitric oxide production in RAW 264.7 macrophages. Bioorg. Med. Chem. Lett. 2013, 23, 4263-4266.

[66] Lee, S.I.; Yang, J.H.; Kim, D.K. Antioxidant flavonoids from the twigs of Stewartia koreana. Biomol. Ther. 2010, 18, 191-196.

[67] Kataya, A.H.H.; Hamza, A.A. Red cabbage (Brassica oleracea) ameliorates deiabetic nephropathy in rats. eCAM 2008, 5, 281-287.

[68] Sayed A.A. Ferulsinaic acid attenuation of diabetic nephropathy. Eur. J. Clin. Invest. 2013, 43, 56-63.

[69] Mazzone, G.; Malaj, N.; Galano, A.; Russo, N.; Toscano, M. Antioxidant properties of several coumarin-chalcone hybrids from theoretical insights. RSC Adv. 2015, 5, 565-575.

[70] Mazzone, G.; Galano, A.; Alvarez-Idaboy, J.R.; Russo, N. Coumarin-Chalcone Hybrids as Peroxyl Radical Scavengers: Kinetics and Mechanisms J. Chem. Inf. Model. 2016, 56(4), 662-670.

[71] Laupattarakasem, P.; Houghton, P.J.; Hoult, J.R.S. Anti-inflammatory isoflavonoids from the stems of Derris scandens. Planta Med. 2004, 70(6), 496-501.

[72] Xiao, J.; Zhang, Q.; Gao, Y.-Q.; Tang, J.-J.; Zhang, A.-L.; Gao, J.-M. Secondary metabolites from the endophytic Botryosphaeria dothidea of Melia azedarach and their antifungal, antibacterial, antioxidant, and cytotoxic activities. J. Agr. Food Chem. 2014, 62(16), 3584-3590.

[73] Tantry, M.A.; Rahman, A.A. Amplexicine, an antioxidant flavan-3-ol from Polygonum amplexicaule. Nat. Prod. Commun. 2011, 6(1), 1597-1598.

[74] Chan, Y.-Y.; Li, C.-H.; Shen, Y.-C.; Wu, T.-S. Anti-inflammatory principles from the stem and root barks of Citrus medica. Chem. Pharm. Bull. 2010, 58(1), 61-65. 
[75] Yoshikawa, K.; Kawahara, Y.; Arihara, S.; Hashimoto, T. Aromatic compounds and their antioxidant activity of Acer saccharum. J. Nat. Med. 2011, 65(1), 191-193.

[76] Mohammadi, M.; Yousefi, M.; Habibi, Z.; Shafiee, A. Two new coumarins from the chloroform extract of Angelica urumiensis from Iran. Chem. Pharm. Bull., 2010, 58(4), 546548.

[77] Rizk, E.T.; Hassan, S.M.M. Molluscicidal activity of furanocoumarins isolated from Ammi majus against Biomphalaria alexandrina snails. Egypt. J. Pharm. Sci. 2000, 40(1), 61-71.

[78] Menichini, G.; Alfano, C.; Provenzano, E.; Marrelli, M.; Statti, G.A.; Menichini, F.; Conforti, F. Cachrys pungens Jan inhibits human melanoma cell proliferation through photoinduced cytotoxic activity. Cell Proliferat. 2012, 45(1), 39-47.

[79] Ng, T.B.; Liu, F.; Wang, Z.T. Antioxidative activity of natural products from plants. Life Sci. 2000, 66(8), 709-723.

[80] Senol, F.S.; Wozniak, K.S.; Khan, M.T.H.; Orhan, I.E.; Sener, B.; Glowniak, K. An in vitro and in silico approach to cholinesterase inhibitory and antioxidant effects of the methanol extract, furanocoumarin fraction, and major coumarins of Angelica officinalis L. fruits. Phytochem. Lett. 2011, 4(4), 462-467.

[81] Bertin, R.; Chen, Z.; Martinez-Vazquez, M.; Garcia-Argaez, A.; Froldi, G. Vasodilation and radical-scavenging activity of imperatorin and selected coumarinic and flavonoid compounds from genus Casimiroa. Phytomedicine 2014, 21, 586-594.

[82] Piao, X.L.; Park, I.H.; Baek, S.H.; Kim, H.Y.; Park, M.K.; Park, J.H. Antioxidative activity of furanocoumarins isolated from Angelicae dahuricae. J. Ethnopharmacol. 2004, 93, 243246.

[83] Wang, C.-C.; Lai, J.-E.; Chen, L.-G.; Yen, K.-Y.; Yang, L.-L. Inducible nitric oxide synthase inhibitor of Chinese herbs part II: Naturally occurring furanocoumarins. Bioorg. Med. Chem. 2000, 8(12), 2701-2707.

[84] Phuwapraisirisan, P.; Surapinit, S.; Tip-pyang, S. A novel furanocoumarin from Feroniella lucida exerts protective effect against lipid peroxidation. Phytother. Res. 2006, 20(8), 708-710.

[85] Parshad, B.; Duraisamy, A.J.; Saini, S.; Yadav, P.; Vats, P.; Sunil, K.S. Synthesis and SAR study of antioxidant potential of polyhydroxy coumarin derivatives. Med. Chem. 2016, 6, 506-514.

[86] Nampoothiri, S.V.; Esakkidurai, T.; Pitchumani, K. Identification and quantification of phenolic compounds in Alpinia galanga and Alpinia calcarata and its relation to free radical quenching properties: A comparative study. J. Herbs. Spices Med. Plants. 2014, 21, 140-147. [87] Ribeiro, A.B.; Chisté, R.C.; Freitas, M.; Fiori da Silva, A.; Visentainer, J.V.; Fernandes, E. Psidium cattleianum fruit extracts are efficient in vitro scavengers of physiologically relevant reactive oxygen and nitrogen species. Food Chem. 2014, 165, 140-148.

[88] Zhou, Z.H.; Liu, M.Z.; Wang, M.H.; Qu, W.; Sun, J.B.; Liang, J.Y.; Wu, F.H. A new ellagic acid derivative from Polygonum runcinatum. Nat. Prod. Res. 2015, Ahead of print.

[89] Granica, S.; Czerwińska, M.E.; Piwowarski, J.P.; Ziaja, M.; Kiss, A.K. Chemical composition, antioxidative and anti-inflammatory activity of extracts prepared from aerial parts of Oenothera biennis L. and Oenothera paradoxa Hudziok obtained after seeds cultivation. J. Agric. Food Chem. 2013, 61, 801-810. 
[90] Arya, A.; Nyamathulla, S.; Noordin, M.I.; Mohd, M.A. Antioxidant and hypoglycemic activities of leaf extracts of three popular Terminalia species. E-J. Chem. 2012, 9, 883-892. 